\title{
Editorial \\ Vitamin D's Role in Reducing Risk of SARS-CoV-2 and COVID-19 Incidence, Severity, and Death
}

\author{
William B. Grant
}

check for

updates

Citation: Grant, W.B. Vitamin D's Role in Reducing Risk of SARS-CoV-2 and COVID-19 Incidence, Severity, and Death. Nutrients 2022, 14, 183 https://doi.org/10.3390/nu14010183

Received: 20 December 2021 Accepted: 27 December 2021 Published: 31 December 2021

Publisher's Note: MDPI stays neutral with regard to jurisdictional claims in published maps and institutional affiliations.

Copyright: (C) 2021 by the author. Licensee MDPI, Basel, Switzerland. This article is an open access article distributed under the terms and conditions of the Creative Commons Attribution (CC BY) license (https:// creativecommons.org/licenses/by/ $4.0 /)$
Sunlight, Nutrition and Health Research Center, P.O. Box 641603, San Francisco, CA 94164-1603, USA; williamgrant08@comcast.net; Tel.: +1-415-409-1980

The article by D'Avolio and colleagues [1] on patients with a positive polymerase chain reaction (PCR) test for SARS-CoV-2 was the first to report that 25-hydroxyvitamin $\mathrm{D}[25(\mathrm{OH}) \mathrm{D}]$ concentrations were lower in PCR-positive patients than in PCR-negative patients or in historical controls. As a result, that report has the most citations in its category (201 according to SCOPUS on 17 December 2021). Thus, the article likely helped considerably stimulate investigation of vitamin D's role in reducing risk of SARS-CoV-2 infection and ensuing COVID-19.

A later article on $25(\mathrm{OH}) \mathrm{D}$ concentration and risk of SARS-CoV-2 positivity was based on more than 190,000 PCR tests on patients in the U.S. with serum 25(OH)D concentration measurements from the previous 12 months on file by quest diagnostics [2]. According to that report, positivity was inversely correlated with seasonally adjusted $25(\mathrm{OH}) \mathrm{D}$ concentration, posing a risk for patients with concentrations of $\sim 55 \mathrm{ng} / \mathrm{mL}$ have about half the positivity of those with concentrations of $<20 \mathrm{ng} / \mathrm{mL}$.

A recent meta-analysis involving 76 studies reported inverse correlations for COVID19 risk with respect to serum $25(\mathrm{OH}) \mathrm{D}$ concentrations for risk of developing the disease, its severity, and risk of death [3], thus offering support for the role of vitamin D in reducing risk of COVID-19.

However, because of the concern that having an acute inflammatory illness could lower serum 25(OH)D concentrations [4], observational studies of COVID-19 using 25(OH)D concentrations measured at or near time of diagnosis have been questioned. The data in Figure 3 of reference [3] can be used to address that concern. The 19 studies can be divided into four categories: 25(OH)D at time of diagnosis (seven studies); within 1 year prior (eight); preceding 10 years (one); and 10-15 years prior (three). The mean weighted odds ratios for each time are $2.08,1.76,1.27$, and 1.04 , respectively. Those values are consistent with a longer interval between blood draw and health outcome, which are associated with worse health outcomes due to changes in $25(\mathrm{OH}) \mathrm{D}$ concentrations. That effect is most pronounced for diseases that can develop rapidly, such as breast cancer [5]. Although the present editorial does not rule out reduction in 25(OH)D due to COVID-19, the times before diagnosis are independent of COVID-19 and support the role of vitamin D in reducing risk.

The innate immune system mechanisms by which vitamin D reduces risk of SARSCoV-2 infection and COVID-19 appear to include reduced viral viability and replication by inducing cathelicidin and defensins as well as reduced production of proinflammatory cytokines and the risk of the cytokine storm [6]. Additional mechanisms were suggested later [7]. The innate immune system is not sensitive to the variant of SARS-CoV-2 involved. That is important because the virus mutates easily, thereby reducing the adaptive immune system's ability to respond effectively. Thus, vitamin D can serve as an extra measure of protection as vaccine effectiveness wanes. The recommended serum $25(\mathrm{OH}) \mathrm{D}$ concentration for prevention is 40 to $\geq 60 \mathrm{ng} / \mathrm{mL}$, which could be achieved with 5000 to $10,000 \mathrm{IU} / \mathrm{d}$ vitamin $\mathrm{D}_{3}$, i.e., a safe dose range [8].

Thus, it seems likely that raising serum $25(\mathrm{OH}) \mathrm{D}$ concentrations after SARS-CoV2 infection or development of COVID-19 could reduce the progression and severity of 
COVID-19. Two approaches were attempted with mixed results. The most comprehensive trial of vitamin $\mathrm{D}_{3}$ supplementation with COVID-19 patients was a trial conducted in Turkey [9]. Of 867 COVID-19 patients, 160 patients with initial 25(OH)D concentrations of $<30 \mathrm{ng} / \mathrm{mL}$ were treated with 224,000 to 500,000 IU over periods from 3 to 7 days to achieve $>30 \mathrm{ng} / \mathrm{mL}$. The only clinically significant benefit in comparison with untreated patients with $25(\mathrm{OH}) \mathrm{D}<30 \mathrm{ng} / \mathrm{mL}$ was a reduction in hospital stays over 8 days. However, the length of hospital stay was not significantly different between the two groups. That trial probably failed to achieve significant beneficial effects because the body takes several days to convert vitamin $\mathrm{D}$ to $25(\mathrm{OH}) \mathrm{D}$, during which time the disease progresses, and because the achieved $25(\mathrm{OH}) \mathrm{D}$ concentrations were only $32 \pm 12 \mathrm{ng} / \mathrm{mL}$ on day 7 and $36 \pm 11 \mathrm{ng} / \mathrm{mL}$ on day 14 .

An alternate approach is to supplement with calcifediol [25(OH)D], which raises serum $25(\mathrm{OH}) \mathrm{D}$ concentrations in hours. A successful pilot randomized controlled trial of calcifediol treatment was reported from Barcelona in 2020 [10]. That trial included 76 consecutive COVID-19 patients with acute respiratory tract infection and a positive PCR test for SARS-CoV-2. In addition to standard hospital care, 50 patients were assigned to receive calcifediol treatment: $0.532 \mathrm{mg}$ on the first day, $0.266 \mathrm{mg}$ on days 3 and 7 , and then weekly until discharge or ICU admission. Calcifediol is about 3.2 times more efficient at raising serum $25(\mathrm{OH}) \mathrm{D}$ concentrations than vitamin $\mathrm{D}_{3}$ [11]. Thus, $0.266 \mathrm{mg}$ of calcifediol is equivalent to $\sim 34,000 \mathrm{IU}$ of vitamin $\mathrm{D}_{3}$. Only 1 of 50 patients treated with calcifediol required ICU treatment, as opposed to 13 of 26 not receiving calcifediol ( 2 of whom died).

An observational study in Spain involved 537 patients hospitalized with COVID-19 between 5 February and 5 May 2020, of whom 79 were treated with calcifediol [12]. The odds ratio for mortality within 30 days, adjusted for potential confounders, was 0.16 (95\% confidence interval, 0.03 to 0.80 ).

Funding: No funding was received for this study.

Conflicts of Interest: Sunlight, Nutrition, and Health Research Center receives funding from Bio-Tech Pharmacal, Inc. (Fayetteville, AR, USA).

\section{References}

1. D'Avolio, A.; Avataneo, V.; Manca, A.; Cusato, J.; De Nicolo, A.; Lucchini, R.; Keller, F.; Cantu, M. 25-Hydroxyvitamin D Concentrations Are Lower in Patients with Positive PCR for SARS-CoV-2. Nutrients 2020, 12, 1359. [CrossRef]

2. Kaufman, H.W.; Niles, J.K.; Kroll, M.H.; Bi, C.; Holick, M.F. SARS-CoV-2 positivity rates associated with circulating 25hydroxyvitamin D levels. PLoS ONE 2020, 15, e0239252. [CrossRef]

3. Dissanayake, H.A.; de Silva, N.L.; Sumanatilleke, M.; de Silva, S.D.N.; Gamage, K.K.K.; Dematapitiya, C.; Kuruppu, D.C.; Ranasinghe, P.; Pathmanathan, S.; Katulanda, P. Prognostic and therapeutic role of vitamin D in COVID-19: Systematic review and meta-analysis. J. Clin. Endocrinol. Metab. 2021, dgab892. [CrossRef]

4. Smolders, J.; van den Ouweland, J.; Geven, C.; Pickkers, P.; Kox, M. Letter to the Editor: Vitamin D deficiency in COVID-19: Mixing up cause and consequence. Metabolism 2021, 115, 154434. [CrossRef]

5. Grant, W.B. Long follow-up time and different sensitivities of cancer types may have obscured the effect of 25-hydroxyvitamin D on cancer incidence and mortality rates. Am. J. Clin. Nutr. 2015, 102, 230. [CrossRef]

6. Grant, W.B.; Lahore, H.; McDonnell, S.L.; Baggerly, C.A.; Franch, C.B.; Aliano, J.L.; Bhattoa, H.P. Evidence That Vitamin D Supplementation Could Reduce Risk of Influenza and COVID-19 Infections and Deaths. Nutrients 2020, 12, 988. [CrossRef]

7. Mercola, J.; Grant, W.B.; Wagner, C.L. Evidence Regarding Vitamin D and Risk of COVID-19 and Its Severity. Nutrients 2020, 12, 3361. [CrossRef] [PubMed]

8. McCullough, P.J.; Lehrer, D.S.; Amend, J. Daily oral dosing of vitamin D3 using 5000 TO 50,000 international units a day in long-term hospitalized patients: Insights from a seven year experience. J. Steroid Biochem. Mol. Biol. 2019, 189, 228-239. [CrossRef] [PubMed]

9. Gonen, M.S.; Alaylioglu, M.; Durcan, E.; Ozdemir, Y.; Sahin, S.; Konukoglu, D.; Nohut, O.K.; Urkmez, S.; Kucukece, B.; Balkan, I.I.; et al. Rapid and Effective Vitamin D Supplementation May Present Better Clinical Outcomes in COVID-19 (SARS-CoV-2) Patients by Altering Serum INOS1, IL1B, IFNg, Cathelicidin-LL37, and ICAM1. Nutrients 2021, 13, 4047. [CrossRef]

10. Entrenas-Castillo, M.; Entrenas Costa, L.M.; Vaquero Barrios, J.M.; Alcala Diaz, J.F.; Lopez Miranda, J.; Bouillon, R.; Quesada Gomez, J.M. Effect of calcifediol treatment and best available therapy versus best available therapy on intensive care unit admission and mortality among patients hospitalized for COVID-19: A pilot randomized clinical study. J. Steroid Biochem. Mol. Biol. 2020, 203, 105751. [CrossRef] [PubMed] 
11. Quesada-Gomez, J.M.; Bouillon, R. Is calcifediol better than cholecalciferol for vitamin D supplementation? Osteoporos. Int. 2018, 29, 1697-1711. [CrossRef] [PubMed]

12. Alcala-Diaz, J.F.; Limia-Perez, L.; Gomez-Huelgas, R.; Martin-Escalante, M.D.; Cortez-Rodriguez, A.L.; Lopez-Carmona, M.D. Calcifediol Treatment and Hospital Mortality Due to COVID-19: A Cohort Study. Nutrients 2021, 13, 1760. [CrossRef] [PubMed] 